\title{
Estimating Discounts for Top Spending Drugs in Medicare Part D
}

J Gen Intern Med 36(8):2503-5

DOI: $10.1007 / \mathrm{s} 11606-020-06194-2$

(c) Society of General Internal Medicine 2020

\section{INTRODUCTION}

In 2010-2016, US gross drug spending grew by $30 \%$, exceeding $\$ 450$ billion in 2016. ${ }^{1,2}$ Net spending, however, grew slower due to manufacturer discounts ${ }^{2}$ - mostly in the form of rebates to insurers and pharmaceutical benefit managers negotiated in exchange for placement of drugs in preferred formulary tier. The Government Accountability Office estimates that in 2016 manufacturer discounts in Medicare Part D accounted for $\$ 29$ billion, or $20 \%$ of Part D spending. ${ }^{3}$ Due to the confidential nature of negotiations, rebates and discounts are proprietary, and prior research has not been able to identify which drugs account for the majority of these discounts. We used indirect estimates of discounts from SSR Health ${ }^{4} 5$ to identify the top drugs and therapeutic classes contributing to manufacturer discounts in Part D.

\section{METHODS}

Using the Medicare Part D spending dashboard, ${ }^{6}$ we identified 6 high-expenditure therapeutic classes with large rebates based on prior research, ${ }^{5}$ including insulins, non-insulin antidiabetics, inhalers, hepatitis C direct-acting antivirals (DAAs), direct oral anticoagulants (DOACs), and tumor necrosis factor (TNF) inhibitors. We extracted total Medicare Part D spending in 2016 for all drugs within these classes $(n=80)$.

We obtained SSR Health data on discounts for branded medications whose US sales are reported by publicly traded companies. ${ }^{7}$ These data have been used in peer-reviewed research. ${ }^{4,}{ }^{5}$ SSR Health estimates prices net of discounts by dividing company-reported sales for each product by the number of units sold. ${ }^{7}$ Discounts are estimated as the difference between list and net prices, and are separately calculated for Medicaid and other payers.

For each drug in selected therapeutic classes, we estimated Part D discounts in 2016 US dollars by multiplying total

Received May 1, 2020

Accepted August 27, 2020

Published online September 9, 2020 spending reported in the dashboard by the 2016 average non-Medicaid discount from SSR Health. We used the nonMedicaid discount because SSR Health is not able to separately estimate discounts for Medicare. ${ }^{5,7}$ We then estimated what proportion of the $\$ 29$ billion in total Medicare Part D discounts was accounted for by each drug and therapeutic class.

There were 20 drugs with missing discount data because they are manufactured by private companies, including tiotropium, ipratropium, and ipratropium/albuterol. In those cases, we used the mean discount for the remaining drugs in the class as the discount estimate and performed sensitivity analyses excluding them. Because SSR Health discounts include not only rebates from manufacturers to payers but also any other manufacturer concession such as coupon cards or 340B discounts, we performed a sensitivity analysis in which we reduce discounts by $25 \%$.

\section{RESULTS}

Discounts and rebates for these six therapeutic classes ranged from $24 \%$ (TNF inhibitors) to $60 \%$ (insulins and DAAs) (Table 1). These six therapeutic classes accounted for nearly $\$ 22$ billion, or $76 \%$ of total manufacturer discounts in Part D. With over $\$ 7$ billion in discounts, insulins accounted for $24 \%$ of discounts in Part D, followed by inhalers ( $\$ 5.3$ billion or $18 \%$ ). After excluding products with missing data, the six therapeutic classes combined accounted for $68 \%$ of total manufacturer discounts. In sensitivity analyses reducing discount estimates by $25 \%$, the six therapeutic classes combined accounted for $55 \%$ of total discounts.

Ten drugs accounted for $\$ 14.3$ billion or $49 \%$ of total manufacturer discounts in Medicare Part D (ledipasvir/ sofosbuvir, insulin glargine, insulin lispro, insulin aspart, fluticasone/salmeterol, sitagliptin, insulin detemir, budesonide/formoterol, rivaroxaban, and apixaban) (Table 2).

\section{DISCUSSION}

In 2016, six therapeutic classes accounted for a large majority of Medicare Part D discounts, with just 10 drugs accounting for nearly half of all Medicare Part D discounts. These findings demonstrate the high concentration of discounts in Part D. 
Table 1 Medicare Part D Gross Spending and Estimated Discounts for Selected Therapeutic Classes, 2016

\begin{tabular}{|c|c|c|c|c|c|c|c|c|}
\hline \multirow[t]{2}{*}{$\begin{array}{l}\text { Therapeutic } \\
\text { class }\end{array}$} & \multirow[t]{2}{*}{$\begin{array}{l}\text { Medicare } \\
\text { Part D } \\
\text { spending }\end{array}$} & \multirow[t]{2}{*}{$\begin{array}{l}\text { Average } \\
\text { discount }\end{array}$} & \multicolumn{2}{|c|}{ Base-case analysis $(n=80)$} & \multicolumn{2}{|c|}{$\begin{array}{l}\text { Sensitivity analyses excluding } \\
\text { drugs with missing discount } \\
\text { information }(n=60)\end{array}$} & \multicolumn{2}{|c|}{$\begin{array}{l}\text { Sensitivity analyses reducing } \\
\text { discount by } 25 \%(n=80)\end{array}$} \\
\hline & & & $\begin{array}{l}\text { Estimated } \\
\text { Part D } \\
\text { discounts }\end{array}$ & $\begin{array}{l}\text { Proportion } \\
\text { of total } \\
\text { Medicare } \\
\text { Part D } \\
\text { discounts }\end{array}$ & $\begin{array}{l}\text { Estimated } \\
\text { Part D } \\
\text { discounts }\end{array}$ & $\begin{array}{l}\text { Proportion of } \\
\text { total Medicare } \\
\text { Part D } \\
\text { discounts }\end{array}$ & $\begin{array}{l}\text { Estimated } \\
\text { Part D } \\
\text { discounts }\end{array}$ & $\begin{array}{l}\text { Proportion of } \\
\text { total Medicare } \\
\text { Part D } \\
\text { discounts }\end{array}$ \\
\hline Insulins & $\$ 12.3 \mathrm{Bn}$ & $60 \%$ & $\$ 7.1 \mathrm{Bn}$ & $24 \%$ & $\$ 7.1 \mathrm{Bn}$ & $24 \%$ & $\$ 5.3 \mathrm{Bn}$ & $18 \%$ \\
\hline Inhalers & $\$ 9.0 \mathrm{Bn}$ & $59 \%$ & $\$ 5.3 \mathrm{Bn}$ & $18 \%$ & $\$ 3.6 \mathrm{Bn}$ & $12 \%$ & $\$ 4.0 \mathrm{Bn}$ & $14 \%$ \\
\hline $\begin{array}{l}\text { Non-Insulin } \\
\text { antidiabetics }\end{array}$ & $\$ 6.6 \mathrm{Bn}$ & $55 \%$ & $\$ 3.5 \mathrm{Bn}$ & $12 \%$ & $\$ 3.5 \mathrm{Bn}$ & $12 \%$ & $\$ 2.6 \mathrm{Bn}$ & $9 \%$ \\
\hline $\begin{array}{l}\text { Hepatitis C } \\
\text { direct-acting } \\
\text { antivirals }\end{array}$ & $\$ 6.4 \mathrm{Bn}$ & $60 \%$ & $\$ 3.5 \mathrm{Bn}$ & $12 \%$ & $\$ 3.1 \mathrm{Bn}$ & $11 \%$ & $\$ 2.3 \mathrm{Bn}$ & $8 \%$ \\
\hline $\begin{array}{l}\text { Direct-acting } \\
\text { oral } \\
\text { anticoagulants }\end{array}$ & $\$ 5.0 \mathrm{Bn}$ & $36 \%$ & $\$ 1.6 \mathrm{Bn}$ & $6 \%$ & $\$ 1.4 \mathrm{Bn}$ & $5 \%$ & $\$ 1.2 \mathrm{Bn}$ & $4 \%$ \\
\hline TNF Inhibitors & $\$ 4.1 \mathrm{Bn}$ & $24 \%$ & $\$ 1.0 \mathrm{Bn}$ & $3 \%$ & $\$ 1.0 \mathrm{Bn}$ & $3 \%$ & $\$ 0.7 \mathrm{Bn}$ & $2 \%$ \\
\hline Total & $\$ 43.0 \mathrm{Bn}$ & & $\$ 22.0 \mathrm{Bn}$ & $76 \%$ & $\$ 19.7 \mathrm{Bn}$ & $68 \%$ & $\$ 16.2 \mathrm{Bn}$ & $55 \%$ \\
\hline
\end{tabular}

As described in the "METHODS" section, gross spending was extracted from the Medicare Part D spending dashboard. ${ }^{6}$ Average discount data was obtained from SSR Health and includes not only rebates from manufacturers to payers but also any other manufacturer concession. Estimated Part D discounts were calculated as the product between gross spending and the average discount. The proportion of total Medicare discounts was estimated as the quotient between the estimated discount for a given class and \$29 billion (total manufacturer discounts in Medicare Part D in 2016). ${ }^{3}$ In sensitivity analyses, we reduced estimates of discounts by $25 \%$ (relative difference). For instance, if the estimated discount for a drug in SSR Health data was $66 \%$, we performed sensitivity analyses using $49.5 \%$ (75\% of $66 \%$ ) as the estimate

Our analysis has two key limitations. We used estimates of discounts from payers other than Medicaid, which includes Medicare and also commercial insurance and the VA. Additionally, discount estimates include not only rebates from manufacturers to payers but also other concessions such as $340 \mathrm{~B}$ discounts or coupon cards, which we addressed in part in sensitivity analyses. While it is unlikely that $340 \mathrm{~B}$ discounts represented a large proportion of discounts for the selected therapeutic classes, there have been recent increases in coupon cards, leading to likely overestimation of discounts in primary analyses.

Table 2 Medicare Part D Gross Spending and Estimated Discounts for the Top Ten Drugs, 2016

\begin{tabular}{|c|c|c|c|c|c|c|c|c|}
\hline \multirow[t]{2}{*}{ Rank } & \multirow[t]{2}{*}{$\begin{array}{l}\text { Brand } \\
\text { name }\end{array}$} & \multirow[t]{2}{*}{$\begin{array}{l}\text { Generic } \\
\text { name }\end{array}$} & \multirow{2}{*}{$\begin{array}{l}\text { Medicare } \\
\text { Part D } \\
\text { spending }\end{array}$} & \multirow[t]{2}{*}{$\begin{array}{l}\text { Average } \\
\text { discount }\end{array}$} & \multicolumn{2}{|c|}{ Base-case analyses } & \multicolumn{2}{|c|}{$\begin{array}{l}\text { Sensitivity analyses reducing } \\
\text { discounts by } 25 \%\end{array}$} \\
\hline & & & & & $\begin{array}{l}\text { Estimated } \\
\text { Part D } \\
\text { discounts }\end{array}$ & $\begin{array}{l}\text { Proportion of } \\
\text { total Medicare } \\
\text { Part D discounts }\end{array}$ & $\begin{array}{l}\text { Estimated } \\
\text { Part D } \\
\text { discounts }\end{array}$ & $\begin{array}{l}\text { Proportion of } \\
\text { Total Medicare } \\
\text { Part D discounts }\end{array}$ \\
\hline 1 & Harvoni & $\begin{array}{l}\text { Ledipasvir/ } \\
\text { sofosbuvir }\end{array}$ & $\$ 4.4 \mathrm{Bn}$ & $66 \%$ & $\$ 2.9 \mathrm{Bn}$ & $10 \%$ & $\$ 2.2 \mathrm{Bn}$ & $7 \%$ \\
\hline 2 & Lantus & $\begin{array}{l}\text { Insulin } \\
\text { glargine }\end{array}$ & $\$ 4.2 \mathrm{Bn}$ & $54 \%$ & $\$ 2.3 \mathrm{Bn}$ & $8 \%$ & $\$ 1.7 \mathrm{Bn}$ & $6 \%$ \\
\hline 3 & Humalog & Insulin lispro & $\$ 2.2 \mathrm{Bn}$ & $70 \%$ & $\$ 1.6 \mathrm{Bn}$ & $5 \%$ & $\$ 1.2 \mathrm{Bn}$ & $4 \%$ \\
\hline 4 & Novolog & Insulin aspart & $\$ 2.3 \mathrm{Bn}$ & $67 \%$ & $\$ 1.5 \mathrm{Bn}$ & $5 \%$ & $\$ 1.2 \mathrm{Bn}$ & $4 \%$ \\
\hline 5 & Advair & $\begin{array}{l}\text { Fluticasone/ } \\
\text { salmeterol }\end{array}$ & $\$ 2.5 \mathrm{Bn}$ & $56 \%$ & $\$ 1.4 \mathrm{Bn}$ & $5 \%$ & $\$ 1.1 \mathrm{Bn}$ & $4 \%$ \\
\hline 6 & Januvia & $\begin{array}{l}\text { Sitagliptin } \\
\text { Phosphate }\end{array}$ & $\$ 2.4 \mathrm{Bn}$ & $54 \%$ & $\$ 1.3 \mathrm{Bn}$ & $5 \%$ & $\$ 1.0 \mathrm{Bn}$ & $3 \%$ \\
\hline 7 & Levemir & $\begin{array}{l}\text { Insulin } \\
\text { detemir }\end{array}$ & $\$ 2.0 \mathrm{Bn}$ & $52 \%$ & $\$ 1.0 \mathrm{Bn}$ & $4 \%$ & $\$ 0.8 \mathrm{Bn}$ & $3 \%$ \\
\hline 8 & Symbicort & $\begin{array}{l}\text { Budesonide/ } \\
\text { formoterol }\end{array}$ & $\$ 1.4 \mathrm{Bn}$ & $65 \%$ & $\$ 0.9 \mathrm{Bn}$ & $3 \%$ & $\$ 0.7 \mathrm{Bn}$ & $2 \%$ \\
\hline 9 & Xarelto & Rivaroxaban & $\$ 2.0 \mathrm{Bn}$ & $36 \%$ & $\$ 0.7 \mathrm{Bn}$ & $2 \%$ & $\$ 0.5 \mathrm{Bn}$ & $2 \%$ \\
\hline 10 & Eliquis & Apixaban & $\$ 1.9 \mathrm{Bn}$ & $35 \%$ & $\$ 0.7 \mathrm{Bn}$ & $2 \%$ & $\$ 0.5 \mathrm{Bn}$ & $2 \%$ \\
\hline Total & & & $\$ 25.4 \mathrm{Bn}$ & & $\$ 14.3 \mathrm{Bn}$ & $49 \%$ & $\$ 10.7 \mathrm{Bn}$ & $37 \%$ \\
\hline
\end{tabular}

As described in the "METHODS" section, gross spending was extracted from the Medicare Part D spending dashboard. ${ }^{6}$ Average discount data was obtained from SSR Health and includes not only rebates from manufacturers to payers but also any other manufacturer concession. Estimated Part D discounts were calculated as the product between gross spending and the average discount. The proportion of total Medicare discounts was estimated as the quotient between the estimated discount for a given drug and \$29billion (total manufacturer discounts in Medicare Part D in 2016) ${ }^{3}$

None of the top 10 drugs by estimated discounts had missing data. In sensitivity analyses, we reduced estimates of discounts by 25\% (relative difference). For instance, the estimated discount for Harvoni in SSR Health data was 66\%. Then, we performed sensitivity analyses using $49.5 \%$ (75\% of $66 \%$ ) as the estimate 
Nonetheless, our study demonstrates that the majority of Medicare Part D discounts originate from a few therapeutic classes. These classes include several branded products that are relatively interchangeable and thus compete for formulary placement through discounts.

Inmaculada Hernandez, PharmD, $P h D^{1}$

Alvaro San-Juan-Rodriguez, PharmD ${ }^{1}$

Chester B. Good, $M D, M P H^{2}$

Walid F. Gellad, MD, $M P H^{3}$

${ }^{1}$ Department of Pharmacy and Therapeutics, University of Pittsburgh School of Pharmacy,

Pittsburgh, PA, USA

${ }^{2}$ UPMC Health Plan, Insurance Services Division, Pittsburgh, PA, USA

${ }^{3}$ Division of General Internal Medicine, University of Pittsburgh School of Medicine,

Pittsburgh, PA, USA

Corresponding Author: Inmaculada Hernandez, PharmD, PhD; Department of Pharmacy and Therapeutics, University of Pittsburgh School of Pharmacy, Pittsburgh, PA, USA (e-mail: inh3@pitt.edu).

Funding Hernandez is funded by the National Heart, Lung and Blood Institute (grant number KO1HL142847).

\section{Compliance with Ethical Standards:}

Conflict of Interest: Hernandez discloses scientific advisory board fees from Pfizer, outside of the submitted work. Chester Good is a current employee of the Insurance Services Division, UPMC Health Plan.
Disclaimer: The funder had no role in design and conduct of the study, collection, management, analysis, and interpretation of the data, preparation, review, or approval of the manuscript, and decision to submit the manuscript for publication.

\section{REFERENCES}

1. Yu NL, Atteberry P, Bach PB. Spending On Prescription Drugs In The US: Where Does All The Money Go? Health Affairs Blog. 2018; doi:https://doi. org/10.1377/hblog20180726.670593

2. IQVIA. Medicine Use and Spending in the U.S. 2019; https://www.iqvia com/insights/the-iqvia-institute/reports/medicine-use-and-spending-inthe-us-a-review-of-2018-and-outlook-to-2023. Accessed June 4, 2020.

3. United States Government Accountability Office Report to Congressional Requesters. Medicare Part D Use of Pharmacy Benefit Managers and Efforts to Manage Drug Expenditures and Utilization. 2019; https://www. gao.gov/assets/710/700259.pdf. Accessed December 18, 2019.

4. San-Juan-Rodriguez A, Gellad WF, Good CB, Hernandez I. Trends in List Prices, Net Prices, and Discounts for Originator Biologics Facing Biosimilar Competition. JAMA Netw Open. 2019;2(12):e1917379. https://doi.org/10. 1001/jamanetworkopen.2019.17379

5. Hernandez I, San-Juan-Rodriguez A, Good CB, Gellad WF. Changes in List Prices, Net Prices, and Discounts for Branded Drugs in the US, 20072018. JAMA. 2020;323(9):1-10.

6. Centers for Medicare and Medicaid Services. Medicare Part D Drug Spending Dashboard \& Data. 2019; https://www.cms.gov/ResearchStatistics-Data-and-Systems/Statistics-Trends-and-Reports/Informationon-Prescription-Drugs/MedicarePartD. Accessed December 18, 2019.

7. SSR Health. US Prescription Brand Net Pricing Data and Analysis. 2019; https://www.ssrhealth.com/. Accessed April 24, 2019.

Publisher's Note Springer Nature remains neutral with regard to jurisdictional claims in published maps and institutional affiliations. 